\title{
The impact of active petroleum system on light hydrocarbons distribution in marine sediments
}

\author{
E. Lavrenova ${ }^{1} \cdot$ V. Kerimov ${ }^{1} \cdot$ R Mustaev $^{1}$ (I) $\cdot$ M. Levitskaya ${ }^{2} \cdot$ M. Kruglyakova $^{2}$
}

Received: 21 June 2021 / Accepted: 23 July 2021 / Published online: 4 August 2021

(c) The Author(s) 2021

\begin{abstract}
Integrated interpretation of regional geochemical data and results of the numerical BM\&PSM performed at the east part of the Sea of Azov and northeast part of the Black Sea reveal a correlation between the spatial distribution of light hydrocarbons in seabed sediments and investigated petroleum systems. The obtained results point out that the spatial distribution of gaseous hydrocarbons in marine sediments reflects the geological structure of sedimentary cover, and the maturity of petroleum systems, located within the basins. The origin of background levels and anomalies of light hydrocarbons was explained depending on the present-day petroleum system activity and the structure of overburden rocks.
\end{abstract}

Keywords Petroleum system $\cdot$ Light hydrocarbons $\cdot$ Marine sediments $\cdot$ Geochemical research $\cdot$ Basin modeling . Sedimentary cover

\section{Introduction}

Marine geochemical petroleum prospecting is based on the postulation of subvertical migration of gaseous hydrocarbons from deep oil and gas fields up to sea bottom (Sokolov, 1980; Schumacher 2003, 2017; Starobinets et al., 1993; Wagner et al., 1998; Mackenzie and Quigley, 1988; Brown, 2000). Hence, high amounts of light hydrocarbons $\left(C_{1}-C_{6}\right.$ $\mathrm{HC}$ ) detected in sediments' headspace gas indicate the presence of petroleum accumulation in the sedimentary cover.

As generally assumed (Bazhenova et al., 2000; Starobinets et al., 1993; Larskaya, 1992), there are several sources of $\mathrm{C}_{1}-\mathrm{C}_{6} \mathrm{HC}$ to seabed sediments: migration from the deep part of the sedimentary cover, where hydrocarbons are produced as a result of organic matter thermal destruction (Tisso and Welte, 1970; Hunt, 1982); microbial in situ activity in modern seabed sediments (production of methane mostly); and anthropogenic contamination of marine ecosystems. Their contribution varies under differences

R Mustaev

r.mustaev@mail.ru

1 Sergo Ordzhonikidze Russian State University for Geological Prospecting, Moscow, Russian Federation

2 JSC "Yuzhmorgeologiya", Gelendzhik, Russian Federation in geological, ecological, and microbiological conditions (Jones and LeBlanc 2004, Michael and Abrams, 2020).

The investigated distribution of $\mathrm{C}_{1}-\mathrm{C}_{6} \mathrm{HC}$ in the quaternary sediments in the vicinity of the Black Sea and the Sea of Azov discloses the low contribution of microbial and anthropogenic processes. Also, background (BG) levels of light hydrocarbons above main tectonic elements depend strongly on the subsurface geology (Lavrenova and Kruglyakova, 2010).

Both the Black Sea and the Sea of Azov are well-known oil- and gas-bearing basins, where several commercial discoveries and numerous oil and gas shows point out the presence of active petroleum systems (PS) (Fig. 1). Obviously, not only hydrocarbon accumulations take effect on $\mathrm{C}_{1}-\mathrm{C}_{6} \mathrm{HC}$ spatial distribution in the marine sediments, but the whole PS, including a pod of source rock, migration paths, etc.

Thus, the present study focused on the analysis of petroleum systems' impact on light HC distribution in seabed sediments.

\section{Geological setting}

The investigated area includes the east part of the Sea of Azov and the northeast part of the Black Sea (Fig. 2). 


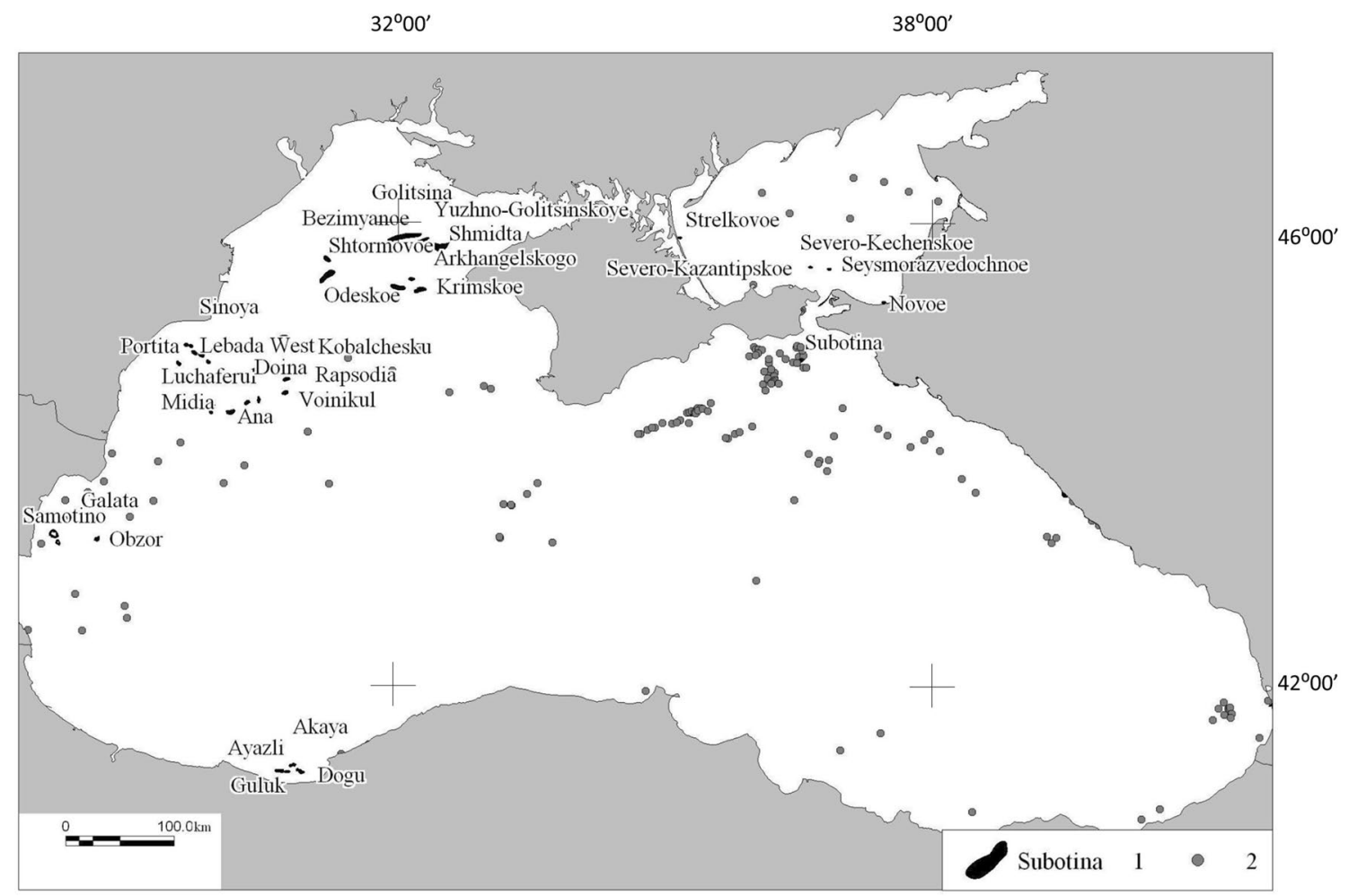

Fig. 1 Distribution of petroleum manifestation within the Black Sea and the Sea of Azov indicates the presence of petroleum systems in the sediment cover of the basins: 1-oil and gas fields, 2-oil and gas shows

Water depths within the Sea of Azov are not more than $13 \mathrm{~m}$. The area belongs to the Scythian Platform, divided into Indolo-Kuban Foredeep, South Azov Step, Azov Swell, North Azov Depression, and Rostov Flunge (Fig. 2). Sediment cover comprises Cretaceous and Cenozoic terrigenous and carbonates sediments above a transitional complex which generally includes Triassic and Lower-Middle Jurassic argillites. The lower part of the transitional complex most likely encompasses Paleozoic deposits.

Water depths within the Black Sea reach $2000 \mathrm{~m}$. The studied area includes the following main tectonic elements: Shatski Ridge, Tuapse Trough, and Novorosiysko-Lazarevski Synclinorium. Sediment cover comprises Upper Mesozoic and Cenozoic predominantly terrigenous sediments (Fig. 2).

Several small gas fields discovered within the Cenozoic system of the Sea of Azov (Strelkovoye, Beysugskoye, Vostochno-Kazantipskoye, etc.), as well as the small oilfield-Novoe, relate to Maykopian and Middle-Upper Miocene plays. Additionally, there are several discoveries in Triassic (Electrorazvedochnaya, Zapadnobeisugskaya) and Eocene deposits (Neizvestnaya). All identified reservoirs are productive mostly gas-saturated. Preliminary investigations indicated that these gas occurrences are most likely genetically associated with the underlying transitional complex. At the northeast part of the Black Sea, oilfield Subbotina and numerous oil shows from mud volcanoes belong to the Maycopian Play. Mesozoic gas fields and some oil shows discovered onshore indicate Mesozoic petroleum system.

\section{Materials and methods}

\section{Geochemical data}

Seabed samples were collected during surveys covering geochemical, geotechnical, and ecological aspects. Investigations were developed by FSC Yuzhmorgeologiya and by Chernomorneftegaz CJSC for 20 years: from 1990 to 2010. The sampling strategy for each investigation was generally determined by its scale. Therefore, the final location plan of the seabed sampling scheme is irregular (Fig. 3).

The concentrations of light hydrocarbons (methane, ethane, propane, butane, pentane, and hexane) measured overall in sediment samples from 2600 sites constitute the geochemical dataset for the present research.

To estimate anthropogenic influences and for better interpretation of the gas-geochemical data, some ecological indicators including concentrations of mineral oil products and amounts of oil-oxidizing bacteria (Oborin \& Stadnik, 1966) in seabed sediments were examined. 
Fig. 2 General location map, showing the geographical and geological settings: $a$ geographical setting, $b$ regional geological setting of the Sea of Azov, $c$ regional geological setting of the Black Sea

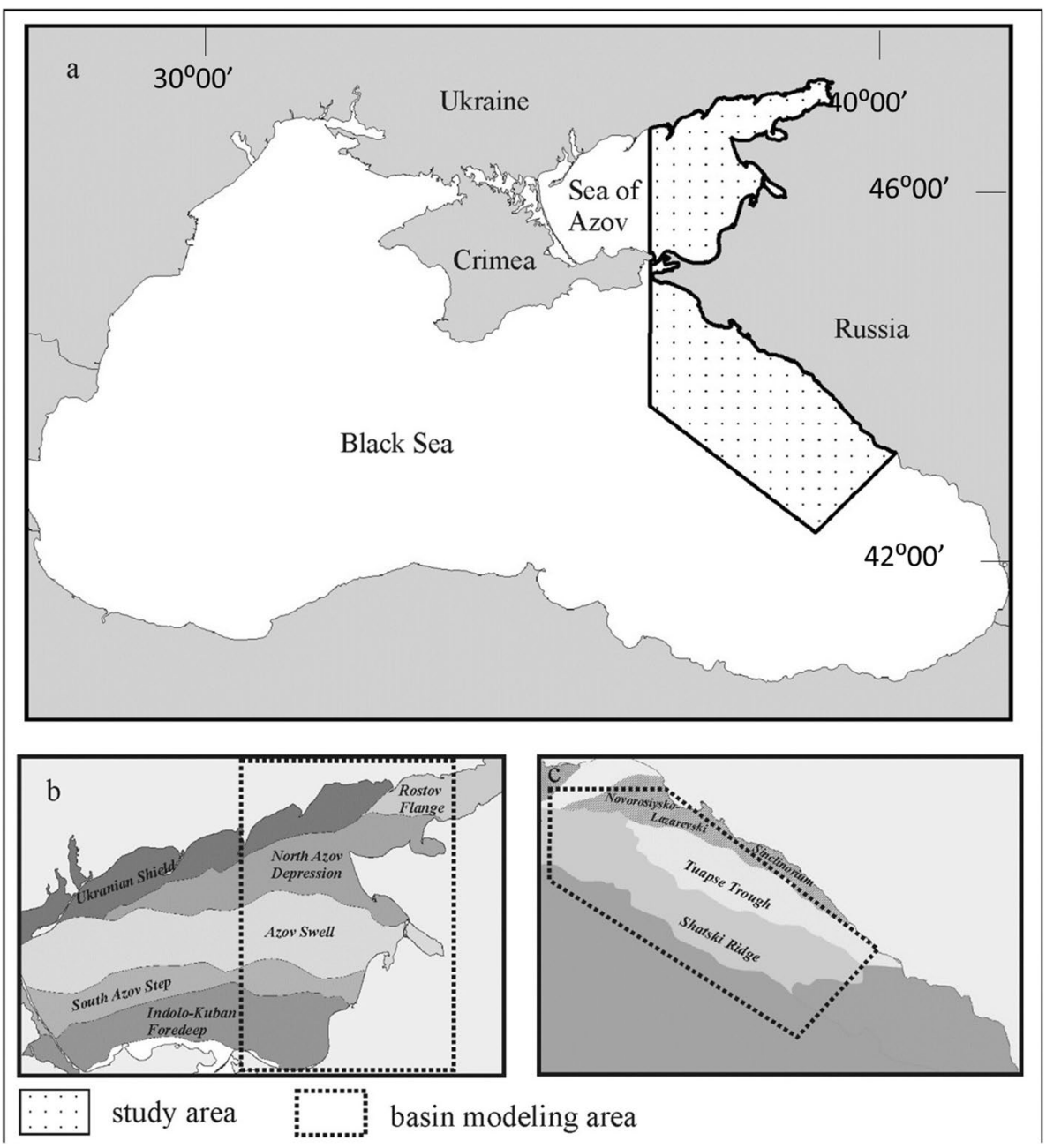

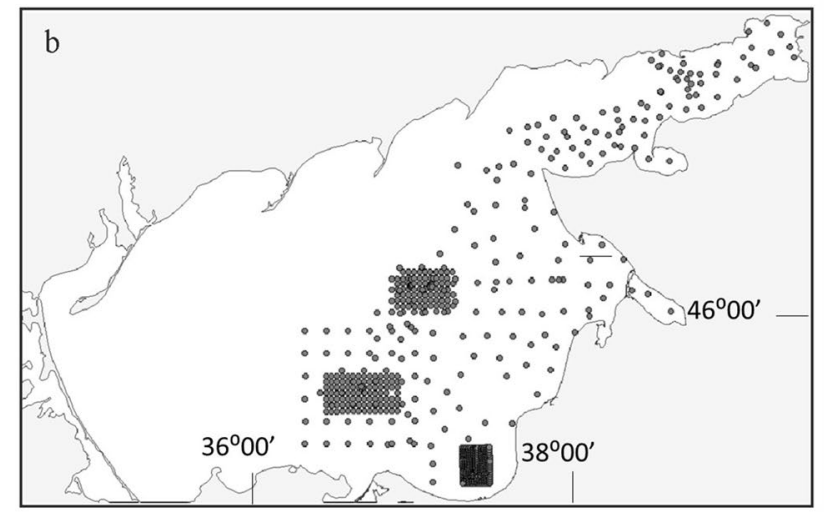

- box and gravity corer location

Fig. 3 Location plan of sediment sampling at $a$ Black Sea and $b$ Sea of Azov

Numerous stable isotope analyses of gaseous hydrocarbons and oils from mud volcanoes and cold seeps at the Black Sea indicate mixing of different sources of $\mathrm{CH}_{4}$ : vertically migrated (thermogenic gas) and an admixture of in situ bacterially generated methane (Blinova, et al., 2003; Bohrmann et al., 2003; Kutas, 2020; Kruglykova R, et al., $2003,2009)$. The source of this biogenic methane is the anaerobic degradation of heavy hydrocarbons coupled to 
methanogenesis (Jiménez et al., 2016; Rabus et al., 2016; Aeckersberg et al., 1991). So microbial activity in marine sediments obscures the isotope signature and decreases the effectiveness of carbon isotope information as a hydrocarbons source indicator. In such cases, next standard indicators involved in interpretation to detect hydrocarbons anomalies origin: high concentrations of hydrocarbon gases uncorrelated with TOC content, high (above background) concentrations of saturated hydrocarbons, $\mathrm{C}_{1} / \sum \mathrm{C}_{2}, \mathrm{C}_{3}, \mathrm{C}_{4}, \mathrm{C}_{5}, \mathrm{C}_{6}$ below 1000, $\sum \mathrm{C}_{2}, \mathrm{C}_{3}, \mathrm{C}_{4} / \sum \mathrm{C}_{5}, \mathrm{C}_{6}$, and a clear predominance of iso-butane over n-butane (Blinova, et al., 2003; Hunt 1982; Bohrmann et al., 2003; Kruglykova et al. 2009; Wagner et al., 1998).

The headspace gas of the sediment samples collected by box corer was extracted on board immediately after the retrieval. Then, it was analyzed by means of a gas chromatograph with a flame ionization detector, and column packed with alumogel or a synthetic sorber. A calibration standard kit for hydrocarbons $\left(\mathrm{C}_{1}-\mathrm{C}_{6}\right)$ was employed for the calculation of concentrations. Detection limits (in vol\%) varied, for $\mathrm{C} 1$, from $1 \times 10-1$ to $1 \times 10-5$; $\mathrm{C} 2$, from $1 \times 10-1$ to $2 \times 10-6$; C3-C6, from $1 \times 10-1$ to $2 \times 10-6$. Accuracy was $\pm 10 \%$.

\section{Statistical data analysis}

The analytical data comprise the concentrations of the light hydrocarbons $\mathrm{C}_{1}$ to $\mathrm{C}_{6}$ detected in seabed sediments. To reduce the number of variables and based on the documented correlations between ethane $\left(\mathrm{C}_{2}\right)$, propane $\left(\mathrm{C}_{3}\right)$, and butane $\left(\mathrm{C}_{4}\right)$ and between pentane $\left(\mathrm{C}_{5}\right)$ and hexane $\left(\mathrm{C}_{6}\right)$, we considered the sum of $\mathrm{C}_{2}-\mathrm{C}_{4}$ and the sum of $\mathrm{C}_{5}-\mathrm{C}_{6}$ as single variables. Thus, methane, sum $\mathrm{C}_{2}-\mathrm{C}_{4}$, and sum $\mathrm{C}_{5}-\mathrm{C}_{6}$ were included in processing and discussion.

The logarithmic mean and standard deviation of each variable were calculated to characterize their distributions. The logarithmic means were regarded as background and observations within one standard deviation of the logarithmic mean-as natural background fluctuations. Individual values were rated as low-contrast anomalies if their values exceeded the background level by more than one standard deviation, as high-contrast anomalies if their values exceeded the background level by more than two standard deviations, and as extraordinary concentrations, if their values exceeded the background level by more than three standard deviations. Mapping of the spatial distributions of geochemical variables was performed based on obtained statistical analysis results.

The results of different geochemical surveys compared using the T-test (Student's) and F-test (Fisher's) enable to ensure that the data were compatible.
Table 1 The models stratigraphy

\begin{tabular}{ll}
\hline The Sea of Azov & The Black Sea \\
\hline Layers & \\
$\mathrm{N}_{3}-\mathrm{Q}$ & $\mathrm{Q}$ \\
$\mathrm{N}_{1-2}$ & $\mathrm{~N}_{2-3}$ \\
$\mathrm{Pg}_{3}-\mathrm{N}_{1}$ (Maikopian) & $\mathrm{N}_{1-2}$ \\
$\mathrm{Pg}{ }_{1-2}$ & $\mathrm{Pg}_{3}-\mathrm{N}_{1}$ (Maikopian) \\
$\mathrm{K}$ & $\mathrm{Pg}_{1-2}$ \\
$\mathrm{~J} 3$ & $\mathrm{~K}$ \\
$\mathrm{~T}-\mathrm{J}_{1-2}$ & $\mathrm{~J}_{3}$ \\
$\mathrm{PZ}(\mathrm{D}-\mathrm{C})$ & $\mathrm{J}_{2}$ \\
\hline
\end{tabular}

\section{Basin modeling}

Basin analysis performed according to principles highlighted by Allen and Allen (2005), Welte et al. (1997), and Hantshel \& Rauerauf (2008) revealed several large sedimentary basins located in the vicinity of the Sea of Azov and the Black Sea. One of them developed within the Sea of Azov from Paleozoic to Cenozoic. The Mesozoic (J-K) Great Caucasus basin existed until the Caucasus orogeny started in Paleogene. After that, the Cenozoic foreland basin of the Tuapse Trough originated (Spadini et al., 1997; Kazmin et al., 2000; Senin et al., 2014).

Basin modeling enables to delineate PS in sedimentary basins situated within the studied area.

Present-day geometry and lithological composition of the Sea of Azov basin model were reconstructed based on published data (Borkov et al. 1994, Tugolesov et al. 1989) and well data drilling reports collected from the Russian State Geological Depository.

All available datasets coming from marine seismic data and the results of onshore and offshore geological surveys (Gorshkov et al. 1989), (Aphansenkov et al. 2007) integrated in course of building the Black Sea basin geometry. The domains of Mesozoic and Cenozoic paleo-basins including shelf, continental slope, and abyssal plane extent onshore as part of Tuapse Trough and NovorosiyskoLazarevski Synclinorium. All of them explored within the northwest Caucasus mountain region, located across the present-day coastline, allow to predict offshore sedimentary rocks lithological composition and stratigraphy despite extremely rare well data.

Thus, both 3D basin models include eight layers (Table 1).

Offshore and onshore seismic data, drilling logs, bottom and outcrop samplings as well as geochemical examination of organic matter (Aphansenkov et al. 2007; Bazhenova et al., 2002; Nadezhkin and Ivanov 2011) provide 
Table 2 The Sea of Azov petroleum systems description

\begin{tabular}{|c|c|c|c|c|c|}
\hline PS name & Essential elements of PS & Rock unit & Lithology & Thickness, m & TOC, $\%$ / HI \\
\hline \multirow[t]{3}{*}{ North Azov Pz (?) } & Reservoir rock & $\mathrm{C}_{3}$ & Carbonate (limestone) & 30 & \\
\hline & Source rock & $\mathrm{C}_{1-2}$ & Terrigenous (shale) & 50 & $3 / 500$ \\
\hline & Seal & $\mathrm{C}_{3}$ & Terrigenous (shale) & 20 & \\
\hline \multirow[t]{3}{*}{ South Azov Mz (?) } & Reservoir rock & $\mathrm{J}_{3}$ & Carbonate (limestone) & 30 & \\
\hline & Source rock & $\mathrm{T}_{3}-\mathrm{J}_{1-2}$ & Terrigenous (shale) & 50 & $2 / 400$ \\
\hline & Seal & $\mathrm{K}$ & Carbonate (marl) & 50 & \\
\hline \multirow[t]{3}{*}{ South Azov CZ (.) } & Reservoir rock & $\begin{array}{l}\text { Middle Maikopian, Miocene } \\
\text { (Chokrakian, Meotis) }\end{array}$ & Terrigenous (sandstone) & 10 & \\
\hline & Source rock & Lower Maikopian & Terrigenous (shale) & 50 & $3 / 400$ \\
\hline & Seal & Upper Maikopian, Miocene & Terrigenous (shale) & 15 & \\
\hline
\end{tabular}

Table 3 The Black Sea petroleum systems description

\begin{tabular}{llllll}
\hline PS name & Essential elements of PS & Rock unit & Lithology & Thickness, m & TOC, \%/ HI \\
\hline Northeast Black Sea Mz (?) & Reservoir rock & $\mathrm{J}_{3}$ & Carbonate (limestone) & 30 & \\
& Source rock & $\mathrm{J}_{1-2}$ & Terrigenous (shale) & 50 & $1.5 / 400$ \\
& Seal & $\mathrm{K}$ & Carbonate (marl) & 50 & 15 \\
CZ PS of Tuapse Trough (.) & Reservoir rock & Middle Maikopian, Miocene & Terrigenous (sandstone) & 15 \\
& Source rock & Lower Maikopian & Terrigenous (shale) & 50 & $1.3 / 300$ \\
& Seal & Upper Maikopian, Miocene & Terrigenous (shale) & 20 & \\
\hline
\end{tabular}

necessary information to ascertain essential petroleum systems elements.

As a result, three petroleum systems were simulated within the east part of the Sea of Azov and two-within the northeast part of the Black Sea (Tables 2,3).

Both models have been simulated with a constant heat flow of $55 \mathrm{~mW} / \mathrm{m}^{2}$ based upon the published data (Chermak et al., 1982; Verzhbitski, 2002; http://www.cnrrb.ru/ geol/heat/index.php). The automatic trend provided by Petromod software for $44^{\circ}$ northern latitude was used to calculate sediment-water interface temperature (Wygrala, 1989). Paleo-water depth maps have been constructed from paleogeographical data.

The model was calibrated using data from all available wells: temperature and vitrinite reflectance. Organic matter maturity (from Rock-Eval analysis) measured in mud volcanic breccia and Mesozoic and Cenozoic rocks from continental slope outcrops was applied to validate the calculated rock maturity in the model. Final verification, using natural petroleum manifestations, reflects their good coincidences with modeled hydrocarbon accumulation.

Results of basin modeling revealed that sediment cover and transitional complex (the upper part of the Scythian
Plate basement, which is not thermally affected or significantly deformed) at the east part of the Sea of Azov include three PS: " "North Azov PZ (.)," "South Azov MZ (?)," and "South Azov CZ (!)" (Figs. 4 and 5). There are at least two PSs in the northeast part of the Black Sea ("Tuapse Trough CZ PS (!)," "Northeast BS MZ PS (?)" (Figs. 5 and 6).

\section{Results and discussion}

The results of petroleum system modeling analyzed according to White (1993, 1998), Magoon and Dow (1994), Magoon (1995), and Magoon and Dow (2000) enable to perform integrated PS maps and cross sections (Figs. 4, 5, 6 , and 7). The main conclusions of performed petroleum system modeling with respect to this study come as follows.

The well-known "South Azov Cenozoic (!)" petroleum system is located within the Indolo-Kuban Foredeep. Petroleum accumulations that are genetically associated with the PS can be expected exclusively in the Upper Cenozoic sediments of Indolo-Kuban Foredeep (Figs. 4 and 5). Lower Maikopian source of petroleum from discovered oil fields of Indolo-Kuban Foredeep was proved by biomarker analysis

\footnotetext{
1 Petroleum systems named after Magoon (1995, 1998, 2004a, b) and Magoon and Dow (1994, 2000).
} 
Fig. 4 The Sea of Azov petroleum system map, showing lateral superposition of simulated PS: 1 source rock of South Azov CZ PS (!), 2 source rock of South Azov MZ PS (?), 3 source rock of North Azov PZ PS (.), 4 geographic extent of PS, 5 oil accumulations, 6 gas accumulations, 7 PS crosssectional position
Fig. 5 The Sea of Azov petroleum system cross section, showing vertical superposition of simulated PS: 1 source rock, 2 geographic and stratigraphic extent of South Azov CZ PS (!), 3 geographic and stratigraphic extent of South Azov MZ PS (?), 4 geographic and stratigraphic extent of North Azov PZ PS (.), 5 fault, 6 gas accumulations, 7 oil accumulations
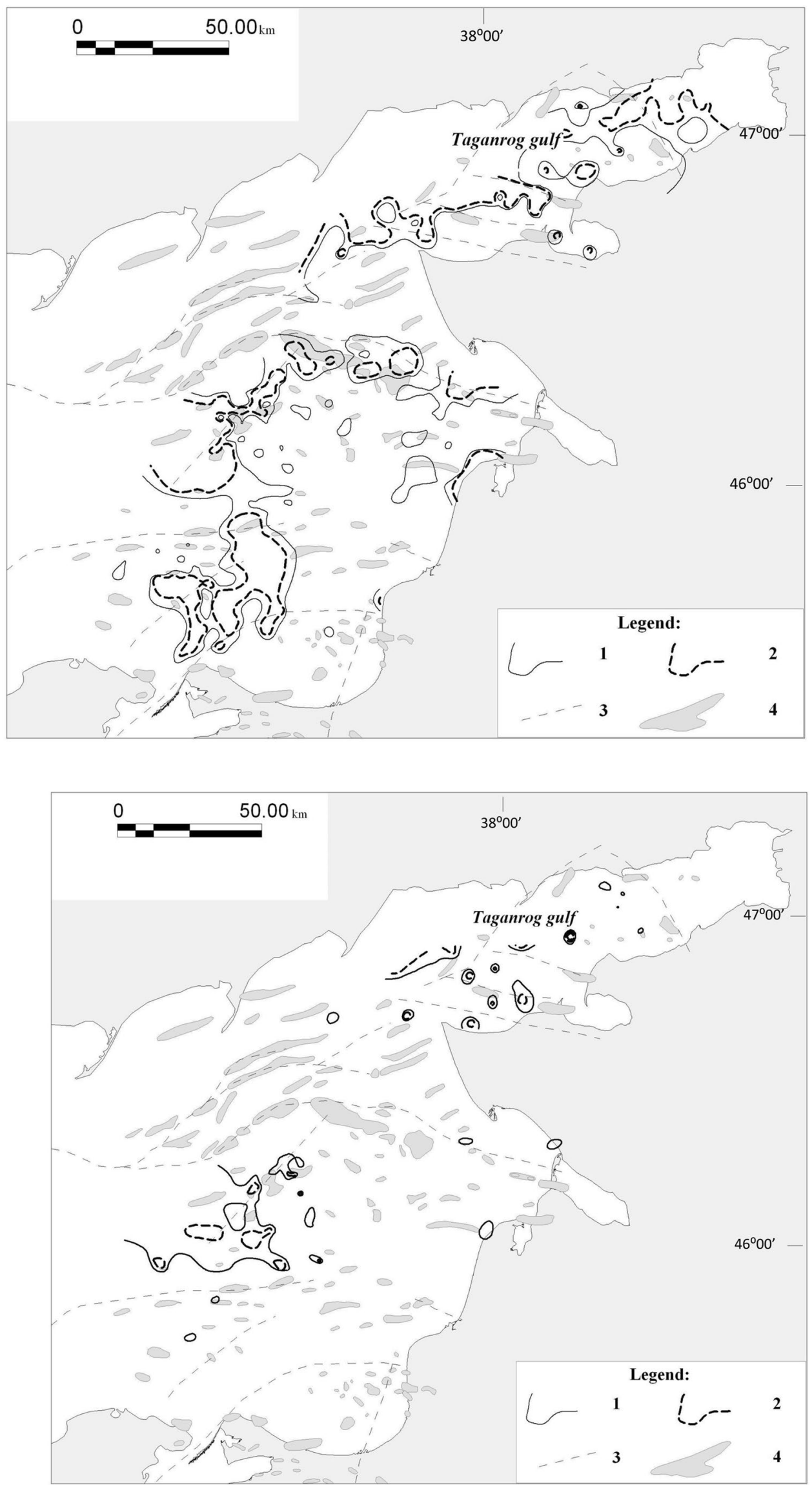
Fig. 6 The Black Sea petroleum system map, showing lateral superposition of simulated PS: 1 source rock of Northeast Black Sea MZ PS (?), 2 source rock of Tuapse Trough CZ PS (!), 3 geographic extent of Northeast Black Sea MZ PS (?), 4 geographic extent of Tuapse Trough CZ PS (!), 5 gas accumulations, 6 oil accumulations, 7 PS crosssectional position

Fig. 7 The Black Sea petroleum system cross section, showing vertical superposition of simulated PS: 1 source rock, 2 geographic and stratigraphic extent of Tuapse Trough CZ PS (!), 3 geographic and stratigraphic extent of Northeast Black Sea MZ PS (?), 4 fault, 5 gas accumulations, 6 oil accumulations
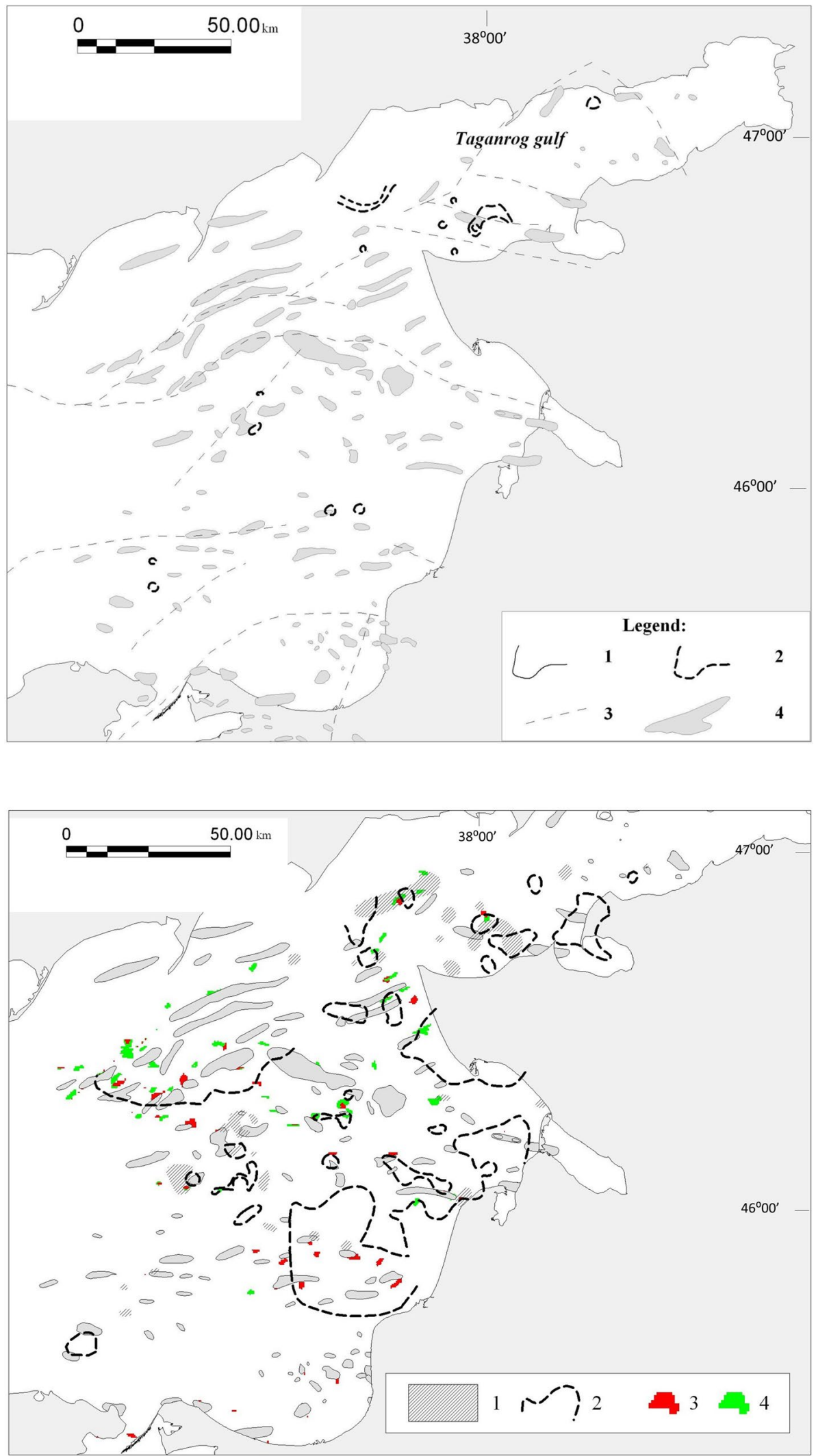
Fig. 8 Spatial distribution of methane in the Sea of Azov seabed sediment, showing enlarge strong anomalies located along the fault zones: 1 low-contrast anomaly, 2 high-contrast anomaly and extraordinary methane concentration, 3 fault, 4 anticline

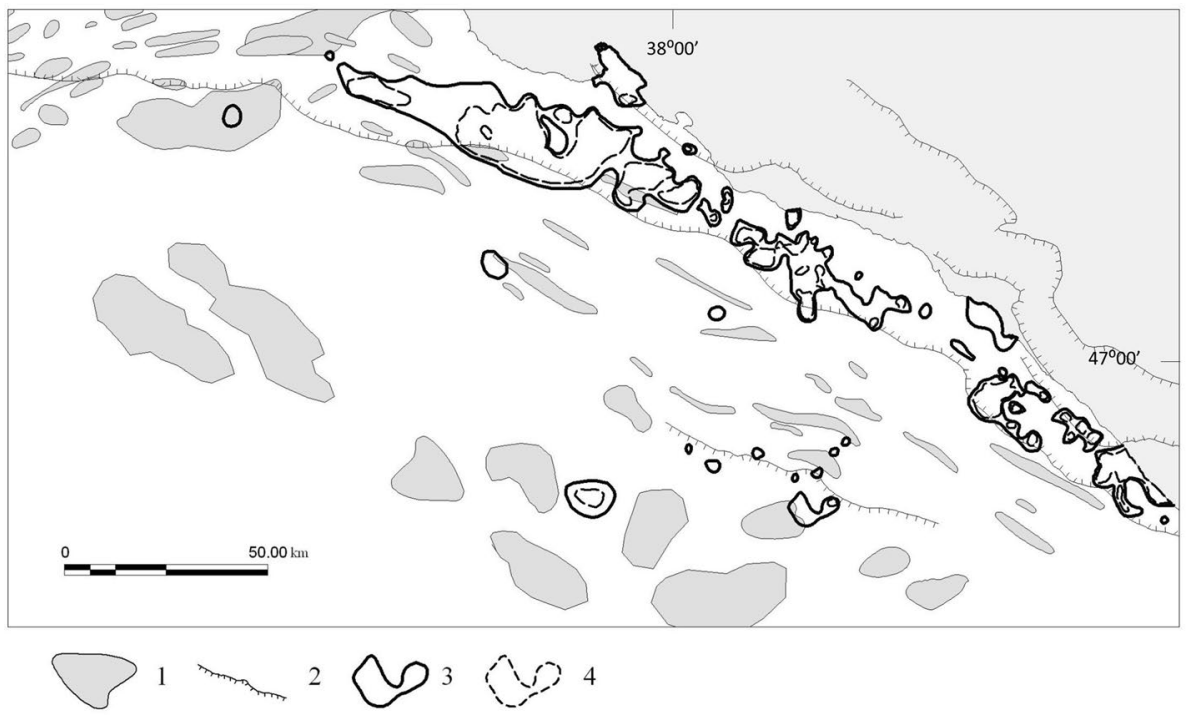

(Bazhenova et al. 2002; Nadezhkin and Ivanov 2011; Ivanov and Lein 2006).

Kitchen of speculative "South Azov MZ (?)" PS, as well as originated accumulations, is located within the South Azov Step (Fig. 6). Middle Jurassic clays are the most possible source rock of the PS (Figs. 4, 5).

The geographic extent of hypothetical "North Azov PZ (.)" PS covers North Azov Depression and Azov Swell (Figs. 4, 5). The direct gas shows, detected in Triassic sediments (boreholes of Oktiabrskaya and Zapadno-Beysugskaya fields), agree with the results of basin modeling and point out the presence of PS in the transitional complex. Oil and gas accumulations that are genetically related to the PS can be expected in traps of the transitional complex within the Azov Swell and North Azov depression. After an extensional tectonic event resulting in the accommodation of normal faults, vertical migration of hydrocarbons was enabled. It seems that hydrocarbons, produced within the transitional complex, have migrated vertically and subsequently infiltrated into the Tertiary sediments deposited along the Azov Swell. So, mainly gas accumulations that are genetically associated with the PS can be predicted also in Upper MZ and CZ sediments of Azov Swell and North Azov Depression.

Known "Tuapse Trough CZ PS (!)," with a pod of active Lower Maikopian source rock, is located within the Tuapse Trough. Oil and gas accumulations, which were produced by the PS, can be expected in the Upper Cenozoic reservoirs of the Trough. Performed biomarker analysis of oil shows from the Tuapse Trough indicates their Lower Maikopian origin (Figs. 6, 7) (Nadezhkin and Ivanov 2011).

Pod of active source rock (Middle Jurassic?) of speculative "Northeast BS MZ PS (?)" is located within the Tuapse Trough and Novorosiysko-Lazarevski Synclinorium. Oil and gas accumulations originated from the pod located along the
Shatski Ridge and Novorosiysko-Lazarevski Synclinorium (Figs. 6, 7).

Previous interpretation of gas-geochemical data perceived organic matter destruction and subsequent migration of gas yield up to the sea bottom as the main factor that affects the spatial distribution of light hydrocarbons in the seabed sediment (Lavrenova and Kruglyakova, 2010). It was evidenced that a background level of light hydrocarbons in marine sediments generally correlated with the thickness of the sediment cover, for example, high background levels were detected above troughs.

This observation is clearly illustrated by the examples from the Sea of Azov. In particular, the Indolo-Kuban Foredeep exhibits the highest background levels, and the Azov Swell-the lowest. In general, a similar situation is observed at the Black Sea. The Taganrog gulf (the Sea of Azov) because of anthropogenic contamination is the only exception within the studied area.

Detected anomalies of light hydrocarbons have mainly natural origins (Figs. 8, 9, 10, 11, 12, 13). The anthropogenic anomalies of methane detected within the Taganrog gulf (Fig. 8) as well as anomalies of methane and sum of $\mathrm{C}_{2}-\mathrm{C}_{4}$, close to Novorossiysk, were considered of technogenic origin (Fig. 11).

Complex tectonic settings of the studied basins provide favorable conditions for vertical migration of hydrocarbons and the development of strong anomalies of all light hydrocarbons (Figs. 8, 9, 10, 11, 12, 13). Thus, extended anomalies of methane, a sum of $\mathrm{C}_{2}-\mathrm{C}_{4}$, and a sum of $\mathrm{C}_{5}-\mathrm{C}_{6}$ generally located along deep faults at the Black Sea (Figs. 11, 12, 13) often exhibit a peculiar hydrocarbons composition with a significantly augmented amount of pentane and hexane. In these cases, ratio $\sum \mathrm{C}_{5}-\mathrm{C}_{6} / \sum \mathrm{C}_{2}-\mathrm{C}_{4}$ exceeded 0.5 in contrast to background levels, where such a ratio generally not exceeds 0.2 (Figs. 10, 11). Under 
Fig. 9 Spatial distribution of sum $\mathrm{C}_{2}-\mathrm{C}_{4}$ in the Sea of Azov seabed sediments, showing prewith the exception of several anomalies grouped within the Taganrog gulf: 1 low-contrast anomaly, 2 high-contrast anomaly and extraordinary HC concentration, 3 fault, 4 anticline dominantly steady distribution

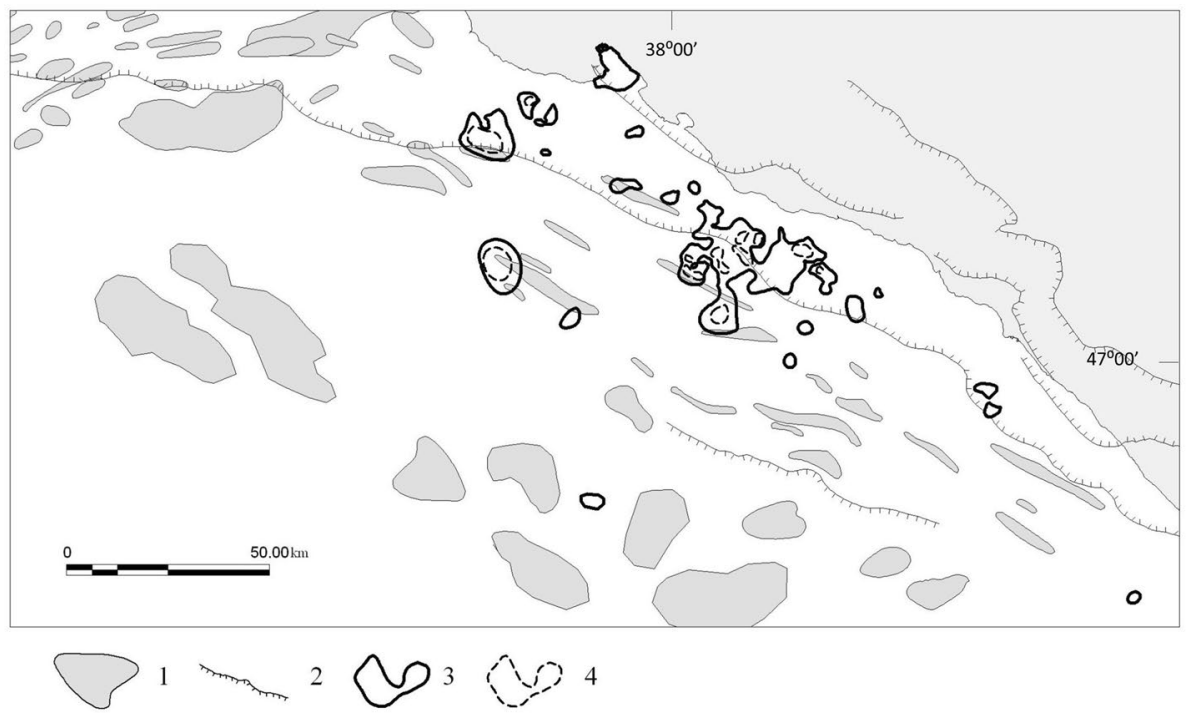

Fig. 10 Spatial distribution of sum $\mathrm{C}_{5}-\mathrm{C}_{6}$ in the Sea of Azov seabed sediments showing enlarge strong anomaly located along the fault zone in the center and group of anomalies located within the Taganrog gulf: 1 low-contrast anomaly, 2 high-contrast anomaly and extraordinary $\mathrm{HC}$ concentration, 3 fault, 4 anticline

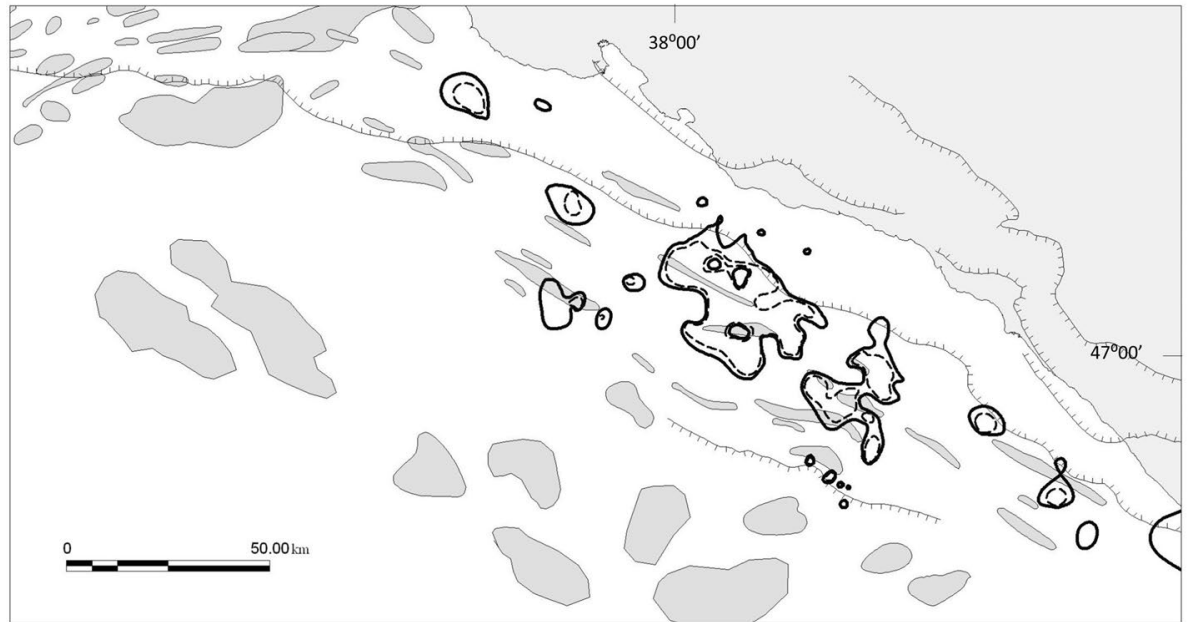

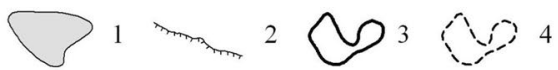

quiet tectonic condition, with reduced intensity of $\mathrm{HC}$ migration, light hydrocarbon anomalies do not arise and there is only an amplified ratio of $\sum \mathrm{C}_{5}-\mathrm{C}_{6} / \sum \mathrm{C}_{2}-\mathrm{C}_{4}$. Local hydrocarbons anomalies coincide with several anticline leads.

Involving into consideration upper mentioned results of BM\&PSM provides a better understanding of the spatial distribution of light $\mathrm{HC}$ in seabed sediments.

It turned out that background levels of light $\mathrm{HC}$ in seabed sediments are not so much due to the thickness of the sedimentary cover (as was assumed prior to this investigation) as to the existence of the pod of active source rock in it (Figs. 14, 15). A possible explanation is that the source rock maturity, its generation, and expulsion rates affect gas composition: Cenozoic petroleum systems provide high background levels of $\sum \mathrm{C}_{2}-\mathrm{C}_{4} \mathrm{HC}$ and Mesozoic $-\sum \mathrm{C}_{5}-\mathrm{C}_{6}$
HC (Table 4). Note that there is no high background level detected above North Azov PZ (.) "kitchen."

Favorable conditions for developing extended light HC anomalies occur in the presence of migration pathways in the overburden rock above the pod of active source rock. Strong anomalies of $\sum \mathrm{C}_{2}-\mathrm{C}_{4}$ and $\sum \mathrm{C}_{5}-\mathrm{C}_{6}$ coincide with the fault zone above the pod of Northeast BS MZ PS (?) and Tuapse Trough CZ (!) petroleum systems affirmed the statement (Figs. 12, 13).

Some small anomalies match with the location of hydrocarbon accumulations expected by the results of petroleum system modeling (Figs. 16, 17). Such a concurrence could be regarded as a sign of the possible petroleum saturation of the traps (Schumacher, 2017).

At the same time, it was ascertained that regional methane anomalies located along the deep faults did not 
Fig. 11 Spatial distribution of methane in the Black Sea seabed sediments, showing extremely strong anomalies located along the faulted zone of regional thrust: 1 anticline, 2 fault, 3 low-contrast anomaly, 4 high-contrast anomaly and extraordinary methane concentration
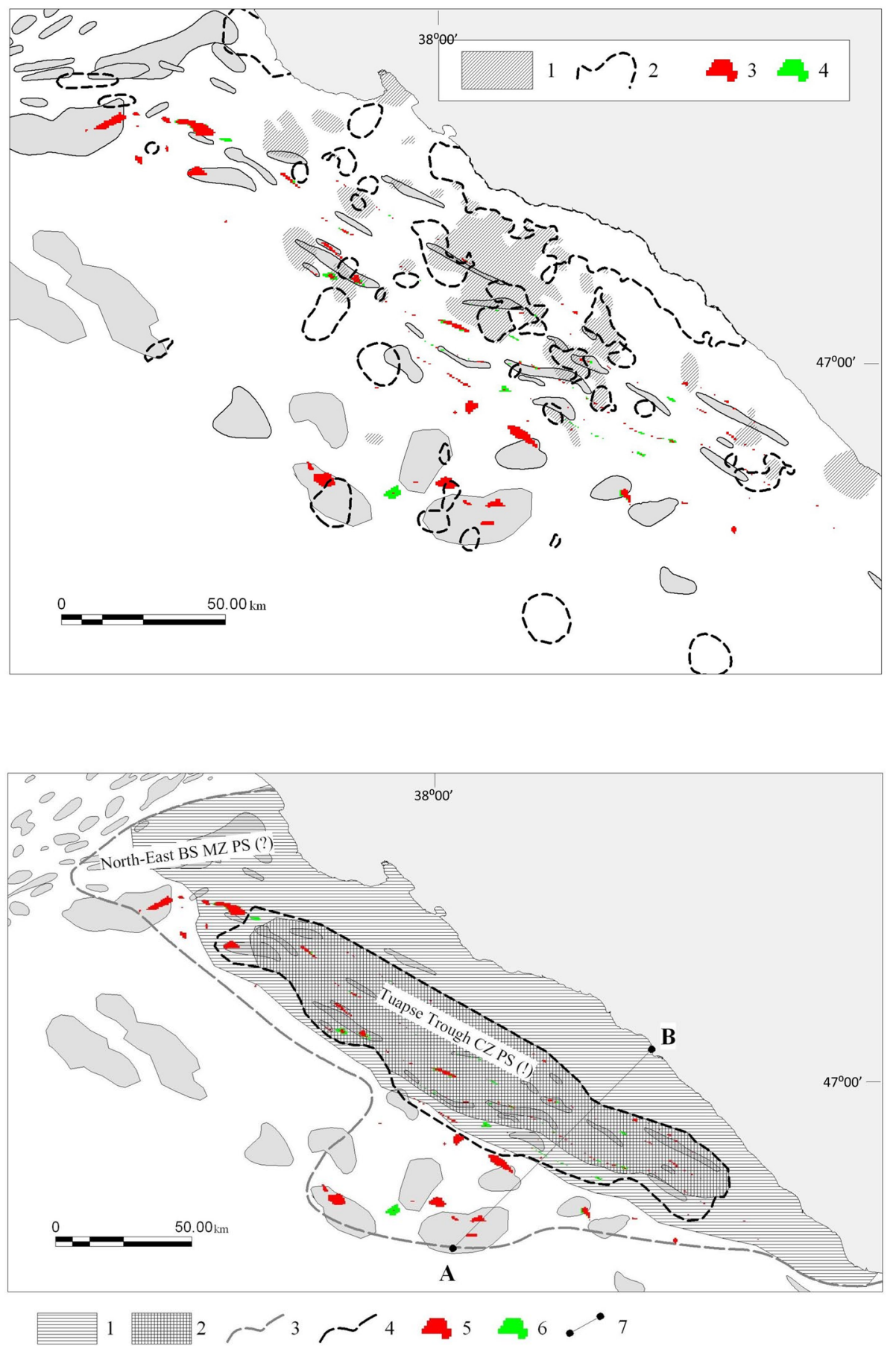

Fig. 12 Spatial distribution of sum $\mathrm{C}_{2}-\mathrm{C}_{4}$ in the Black Sea seabed sediments shows significant variations in distribution with enlarge anomaly in the vicinity of the fault zone and some sparse small anomalies: 1 anticline, 2 fault, 3 low-contrast anomaly, 4 high-contrast anomaly and extraordinary $\mathrm{HC}$ concentration associate with any of the studied PS and possibly are the result of emanation from crust and mantle. The background level of methane in seabed sediments is positively correlated with the thickness of N-Q sediments of sedimentary cover (Figs. 14, 15). It seems methane is produced by the transformation of dispersed organic matter under lower temperatures during the early catagenetic process in the Neogene-Quaternary sediments. And the greater volume of the sediments causes more gas yield. The high mobility of methane provides migration to the sea bottom and a high background level of seabed sediments. 
Fig. 13 Spatial distribution of sum $\mathrm{C}_{5}-\mathrm{C}_{6}$ in the Black Sea seabed sediments showing some strong enlarge anomalies located to the south from fault zone: 1 anticline, 2 fault, 3 lowcontrast anomaly, 4 high-contrast anomaly and extraordinary $\mathrm{HC}$ concentration

Table 4 Correspondence of petroleum systems activity and background level of light $\mathrm{HC}$ in seabed sediments

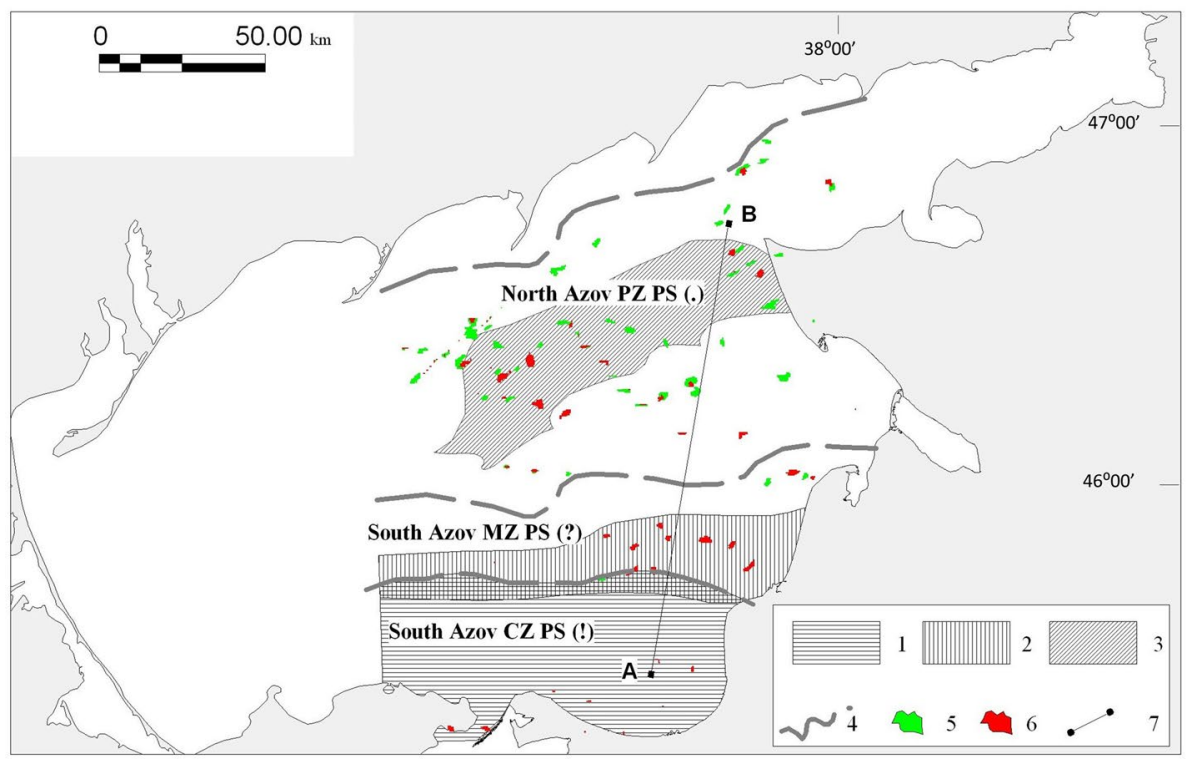

\begin{tabular}{lllll}
\hline Name of PS & $\begin{array}{l}\text { Maximum petroleum } \\
\text { generation rate, Ma }\end{array}$ & $\begin{array}{l}\text { Maximum petroleum } \\
\text { expulsion rate, Ma }\end{array}$ & $\begin{array}{l}\text { Critical } \\
\text { moment, } \\
\text { Ma }\end{array}$ & $\begin{array}{l}\text { High background } \\
\text { level of light HC }\end{array}$ \\
\hline North Azov PZ (.) & 160 & 65 & 50 & - \\
South Azov MZ (?) & 20 & 15 & 15 & Sum of $\mathrm{C}_{5}-\mathrm{C}_{6}$ \\
Northeast BS MZ PS (?) & 30 & 20 & 20 & ${\text { Sum of } \mathrm{C}_{5}-\mathrm{C}_{6}}$ \\
South Azov CZ (!) & 10 & 0 & 0 & ${\text { Sum of } \mathrm{C}_{2}-\mathrm{C}_{4}}$ \\
Tuapse Trough CZ (!) & 16 & 5 & 5 & ${\text { Sum of } \mathrm{C}_{2}-\mathrm{C}_{4}}$
\end{tabular}

A

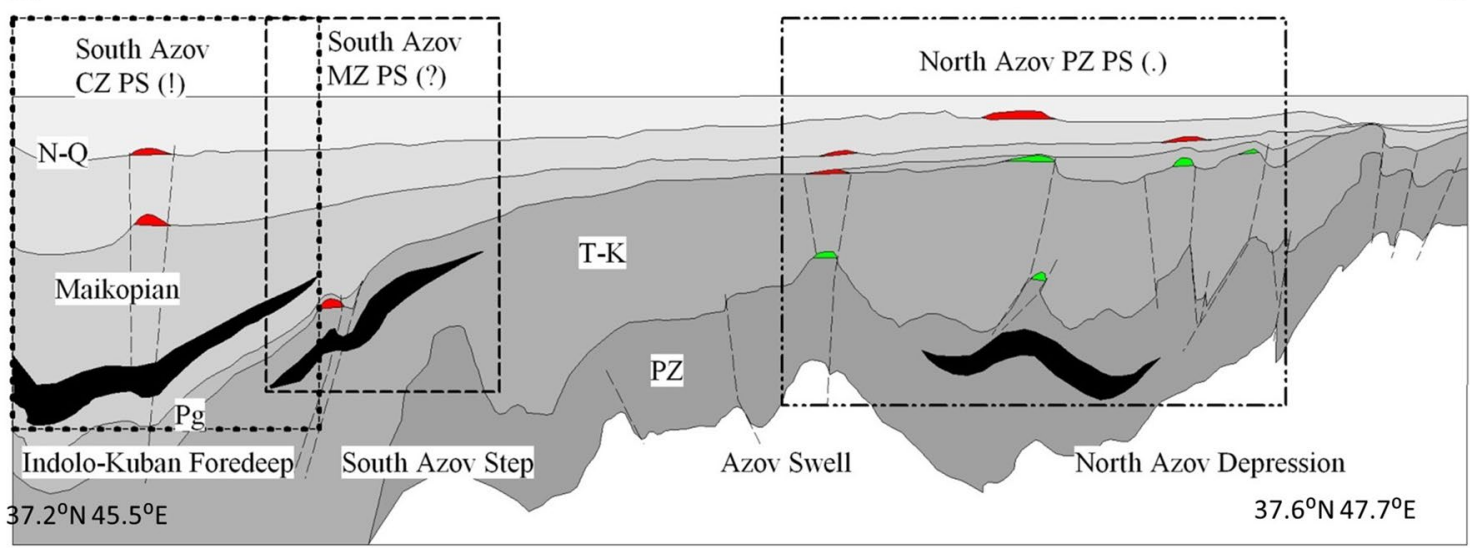

$\square ?$

Fig. 14 Background levels of light HC in the Sea of Azov seabed sediments in respect of petroleum systems, showing the effect of active source rock presence 
Fig. 15 Background levels of light $\mathrm{HC}$ in the Black Sea seabed sediments in respect of petroleum systems, showing the effect of active source rock presence
Fig. 16 Superposition of expected by PS modeling hydrocarbon accumulations and geochemical anomalies at the Sea of Azov, showing some small light $\mathrm{HC}$ anomalies match with the location of the accumulations: 1 light $\mathrm{HC}$ anomalies ( sum $\mathrm{C}_{2}-\mathrm{C}_{4}$ or sum $\mathrm{C}_{5}-\mathrm{C}_{6}$ ), 2 ratio of $\sum \mathrm{C}_{5}-\mathrm{C}_{6} / \sum \mathrm{C}_{2}-\mathrm{C}_{6}$ above $\mathrm{BG}$ level, 3 expected gas accumulation, 4 expected oil accumulation

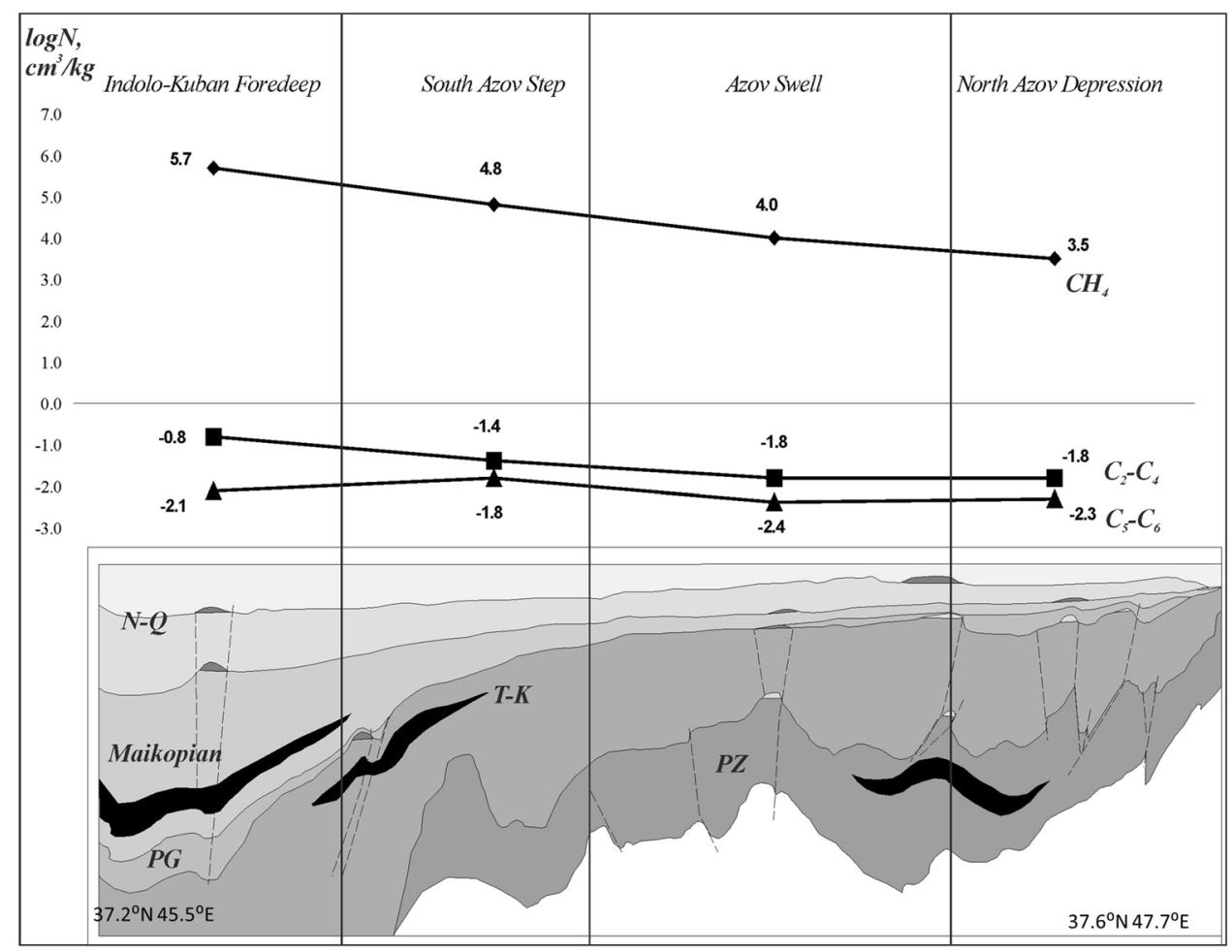

\section{Conclusions}

Performed investigations proved that regional distribution of light hydrocarbons in seabed sediments could be explained by combination of petroleum systems activity and geological structure of overburden rock.
Level of petroleum system maturity governs background level of methane's homologues and gas composition in seabed sediments above the petroleum system kitchen: Cenozoic petroleum systems cause high background level of $\sum \mathrm{C}_{2}-\mathrm{C}_{4}$ and Mesozoic $-\sum \mathrm{C}_{5}-\mathrm{C}_{6}$.

Regional anomalies of light $\mathrm{HC}$ in seabed sediments appear above petroleum system pod where overburden rocks 
Fig. 17 Superposition of expected by PS modeling hydrocarbon accumulations and complex geochemical anomalies at the Black Sea, showing some small light $\mathrm{HC}$ anomalies match with the location of the accumulations: 1 light $\mathrm{HC}$ anomalies (sum $\mathrm{C}_{2}-\mathrm{C}_{4}$ or sum $\mathrm{C}_{5}-\mathrm{C}_{6}$ ), 2 ratio of $\sum \mathrm{C}_{5}-\mathrm{C}_{6} / \sum \mathrm{C}_{2}-\mathrm{C}_{6}$ above $\mathrm{BG}$ level, 3 expected gas accumulation, 4 expected oil accumulation

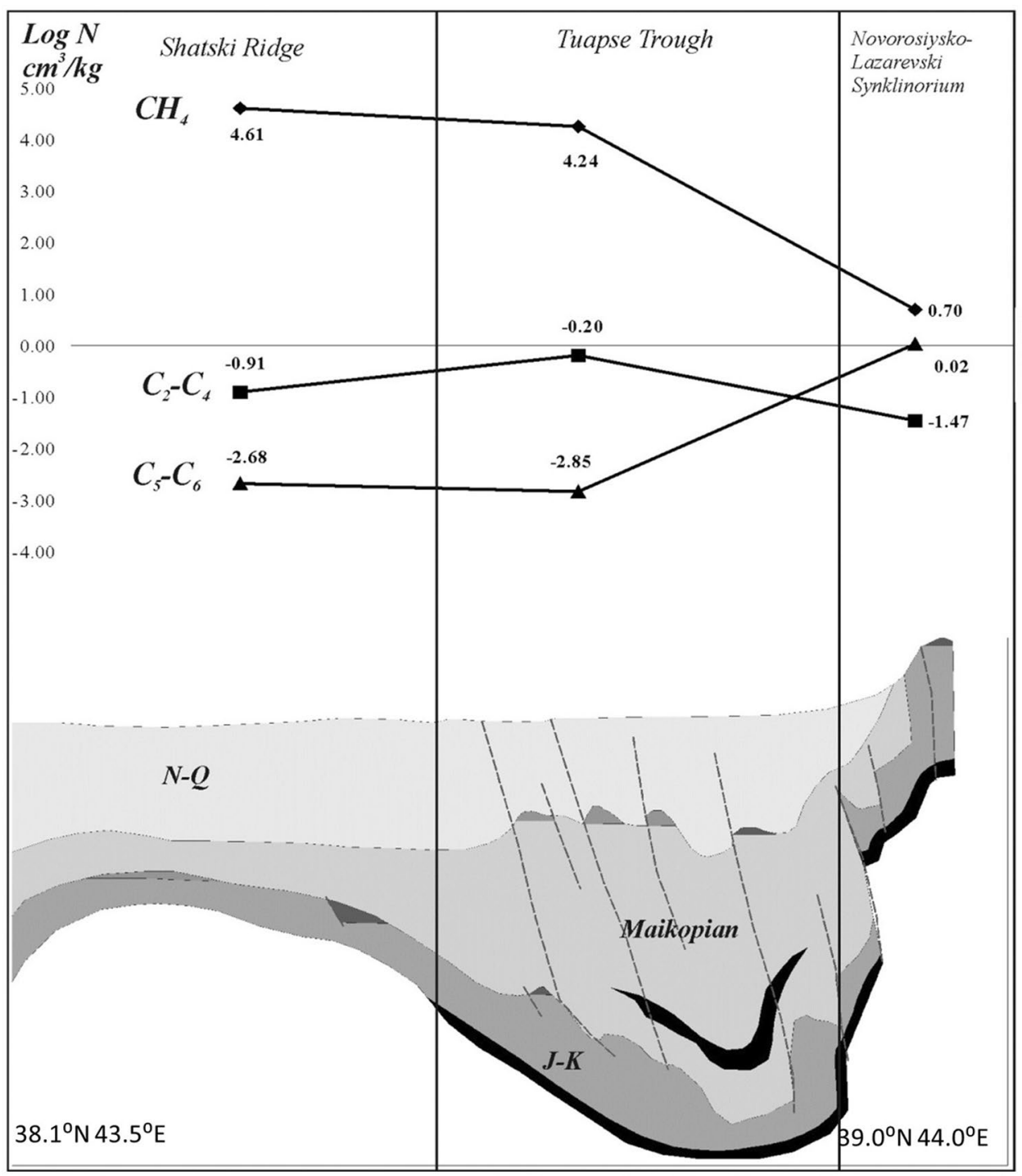

are complicated by faults and local anomalies-above the petroleum accumulations.

The only distribution of methane in marine sediments is not related to the presence of petroleum systems in the sediment cover. Sizable thickness of Miocene-Pliocene deposits causes high BG level of methane in seabed sediments even in the absence of source rock. Regional anomalies of methane are result of emanation from crust and mantle.

Thus, spatial light $\mathrm{HC}$ distribution in seabed sediments reflects geological structure of sedimentary basins and, also, maturity of petroleum systems located within the basins.

Joint interpretation of gas-geochemical data and petroleum system modeling facilitate more effective marine geochemical prospecting and verification of petroleum system models.
Funding The research was completed within the framework of the state assignment of Ministry of Science and Higher Education of the Russian Federation No. 075-00069-20-02 dated September 10, 2020 (theme No. AAAA-A20-120092590017-4).

Availability of data and material Not applicable.

Code availability Not applicable.

\section{Declaration}

Conflict of interest On behalf of all the co-authors, the corresponding author states that there is no conflict of interest.

Open Access This article is licensed under a Creative Commons Attribution 4.0 International License, which permits use, sharing, adaptation, distribution and reproduction in any medium or format, as long as you give appropriate credit to the original author(s) and the source, provide a link to the Creative Commons licence, and indicate if changes were made. The images or other third party material in this article are 
included in the article's Creative Commons licence, unless indicated otherwise in a credit line to the material. If material is not included in the article's Creative Commons licence and your intended use is not permitted by statutory regulation or exceeds the permitted use, you will need to obtain permission directly from the copyright holder. To view a copy of this licence, visit http://creativecommons.org/licenses/by/4.0/.

\section{References}

Aeckersberg F, Bak F, Widdel F (1991) Anaerobic oxidation of saturated hydrocarbons to $\mathrm{CO} 2$ by a new type of sulfate-reducing bacterium. Arch Microbiol 156:5-14

Allen PA, Allen JR (2005) Basin analysis. Principles and applications. Blackwell Publishing, Hoboken, p 549

Aphansenkov A, Nikishin A, Obukhov A (2007) Eastern Black Sea Basin: geological structure and hydrocarbon potential. Scientific World, Moscow, p 172 (in Russian)

Bazhenova OK, Burlin YuK, Khain VE (2000) Geology of oil and gas. In: Sokolova BA (ed) Publishing House of Moscow State University, p 145

Bazhenova O, Fadeeva N, Saint-Germes M, Aref'ev O., Baudin F. (2002) Bimarkers of organic matter in Maikop Rocks and oils of the Caucasian-Scythian region. Geochem Int 40(9):993-1008

Blinova V, Ivanov M, Bohrmann G (2003) Hydrocarbon gases in deposits from mud volcanoes in the Sorokin Trough, north-eastern Black Sea. Geo-Mar Lett 23:250-257. https://doi.org/10.1007/ s00367-003-0148-8

Bohrmann G, Ivanov M, Foucher J-P, Spiess V, Bialas J, Greinert J, Weinrebe W, Abegg F, Aloisi G, Artemov Y, Blinova V, Drews M, Heidersdorf F, Krabbenhöft A, Klaucke I, Krastel S, Leder T, Polikarpov I, Saburova M, Zillmer M (2003) Mud volcanoes and gas hydrates in the Back Sea: New data from Dvurechenskii and Odessa mud volcanoes. Geo-Mar Lett 23:239-249. https:// doi.org/10.1007/s00367-003-0157-7

Borkov F, Golovachev A, Semenduev M, Sherbakov V (1994) Geologic structure and oil and gas bearing of Sea of Azov based on geophysical data. IGIRGI, Moscow

Brown A (2000) Evaluation of possible gas microseepage mechanisms. AAPG Bull 84(11):1775-1789. https://doi.org/10.1306/ 8626C389-173B-11D7-8645000102C1865D

Chermak V, Chapman D, Pollack G et al (1982) The thermal field of Europe. Mir, p 376

Gorshkov A, Meysner L, Tugolecov D et al (1989) Album of Black Sea basin structural maps of Cenozoic deposits. Scale 1:500000, Moscow

Hantshel T, Rauerauf A (2008) Fundamentals of Basin Modeling. Springer Verlag GmbH, p 425

Hunt J (1982) Geochemistry and Geology of Oil and Gas. Mir, p 703

Ivanov MK, Lein AY (2006) Fractionation of stable isotopes of carbon and sulfur during biological processes in the Black Sea. In: Neretin LN (ed) Past and present water column anoxia. Springer, Berlin, pp 373-417

Jiménez N, Richnow H, Vogt C, Treude T, Krüger M (2016) Methanogenic hydrocarbon degradation: evidence from field and laboratory studies. J Mol Microbiol Biotechnol 26:227-242

Jones VT III, LeBlanc RJ Jr (2004) Moore-Johnson (Morrow) field, Greeley County, Kansas: A successful integration of surface soil gas geochemistry with subsurface geology and geophysics: AAPG, Search and Discovery, Article 20022, p 30

Kazmin VG, Shreider AA, Finetti I, Melikhov VR, Bulychev AA, Gilod DA, Andreeva OI, Shreider AV (2000) Early stages of the Black Sea development according to seismic data. Geotektonika, vol 1, pp 45-60
Kruglyakova RP, Kruglyakova MV, Shevtsova NT (2009) Geological and chemical characteristics of natural manifestations of hydrocarbons in the Black Sea. Geol Min World Ocean 1:37-51

Kruglyakova RP, Byakov YA, Kruglyakova MV, Chalenko LA, Shevtsova NT (2004) Natural oil and gas seeps on the Black Sea Floor. Geo-Mar Lett 24:150-162. https://doi.org/10.1007/ s00367-004-0171-4

Kutas R (2020) Geotectonic and geothermal conditions of the gas discharge zones in the Black Sea. Geofizicheskiy Zhurnal 42(5):16-52. https://doi.org/10.24028/gzh.0203-3100.v42i5. 2020.215070

Larskaya ES (1992) Use of geochemical indicators in forecasting oil and gas content. Review: Geology, methods of prospecting, exploration and evaluation of deposits of fuel and energy raw materials, vol 9, p 40

Lavrenova E, Kruglyakova M (2010) Specific features of temporal and spatial distributions of light hydrocarbons in the Sea of Azov. Geo-Mar Lett 30(3):249-260

Mackenzie AS, Quigley TM (1988) Principles of geochemical prospect appraisal. AAPG Bull 72:399-415

Magoon LB, Dow WG (1994) Petroleum system. From Source to Trap AAPG Memoir 60:655

Magoon LB (1988) The petroleum system-a classification scheme for research, exploration, and resource assessments. Geol Surv Bull 1870:2-15

Magoon LB (1995) The play that complements the petroleum system-A new exploration equation. Oil and Gas 93(40):85-87

Magoon LB (2004a) Petroleum system: Nature's Distribution System for oil and Gas. Encyclopedia of Energy 4:823-836

Magoon LB (2004b) Petroleum system: Nature's Distribution System for oil and Gas. Encyclopedia of Energy. 4:823-836

Magoon LB Valin Z (1994) Overview of petroleum system case studies. In: Magoon LB, Dow WG (eds) The Petroleum SystemFrom Source to Trap, AAPG Memoir, vol 60, p 332

Magoon LB, Dow WG (2000) Mapping the petroleum system. An Investigative Technique to Explore the Hydrocarbon Fluid System. . AAPG Mem 73:53-68

Abrams MA (2020) Marine seepage variability and its impact on evaluating the surface migrated hydrocarbon seep signal . Marine Petrol Geol 121:104600

Nadezhkin DV, Ivanov MK (2011) Comparative characteristics of oil biomarkers from subwater and land oil manifestations of the East Black Sea region Geologiya nefti i gaza, pp 80-87

Oborin AA, Stadnik EV (1966) Oil and gas prospecting geomicrobiology. Yekaterinburg, $406 \mathrm{p}$.

Petroleum Geochemistry and Geology, Second Edition Edited by John M. Hunt, W. H. Freeman, et al. 1996. ISBN 0-7167-24413. $743 \mathrm{pp}$

Rabus R, Boll M, Heider J, Meckenstock R, Buckel W, Einsle O, Ermler U, Golding B, Gunsalus R, Kroneck P, Krüger M, Lüders T, Martins B, Musat F, Richnow H, Schink B, Seifert J, Szaleniec M, Treude T, Ullmann G, Vogt C, von Bergen M, Wilkes H (2016) Anaerobic microbial degradation of hydrocarbons : from enzymatic reactions to the environment. J Molec Microbiol Biotechnol. 26(1-3):5-28. https://doi.org/10.1159/ 000443997

Schumacher D (2003) Geochemical Exploration for Oil and GasStrategies for Success. Chapter 18 Gas geochemistry surveys for petroleum https://www.researchgate.net/publication/284404202

Schumacher D (2017) Minimizing Exploration Risk: The Impact of Hydrocarbon Detection Surveys for Distinguishing Charged from Uncharged Traps, April 2017 Conference: AAPG Annual Meeting, April, At: Houston, TX

Senin B, Kruglykova M, Lavrenova E, Leonchick M, Gorbunov A (2014) Palaeogeography of the North-Eastern Black Sea and the Western Caucasus in Mesozoic and Cenozoic 6th Saint 
Petersburg International Conference \& Exhibition - Geosciences - Investing in the FutureSaint Petersburg, Russia.

Sokolov BA (1980) Evolution and oil and gas content of sedimentary basins. Nauka, $243 \mathrm{p}$

Spadini G, Robinson AG, Cloetingh S (1997) Thermomechanical modeling of Black Sea basin formation subsidence and sedimentation. Regional and Petroleum geology of the Black Sea and Surrounding Areas. AAPG Mem 68:19-38

Starobinets IS, Petukhov AV, Zubayrev SL (1993) Fundamentals of the theory of geochemical fields. Nedra, $332 \mathrm{p}$

T. Ruan, QF(2000) Chapter 6 Gas geochemistry surveys for petroleum, Editor(s): M. Hale, Handbook of Exploration Geochemistry, Elsevier Science B.V., Volume 7, Pages 213-231, ISSN 0168-6275, ISBN 9780444504395

Thermal field of the Caucasian region // Natural risks and natural resources of the North Caucasus / Electronic resource / http: //www.cnrr.ru.

Tissot B, Welte D (1970) Formation and distribution of oil. Nedra, $309 \mathrm{p}$.
Verzhbitsky EV (2002) Heat flow and age of the Black Sea. Oceanology 42(6):S881-S887

Wagner M, Rash HJ, Piske J, Baum M (1998) MPOG - Microbial prospecting for oil and gas/Field examples and their geological background, Conference, Cracow, Poland, pp 118-121

Welte DH, Horsfield B, Baker DR (1997) Petroleum and basin Evolution. Springer, Berlin, p 536

White DA (1988) Oil and Gas Play Maps in Exploration and Assessment: GEOLOGIC NOTE1. AAPG Bull 72:944-949

White DA (1993) Geologic risking guide for prospects and plays. AAPG Bull 77:2048-2061

Wygrala BP (1989) Integrated study of an oil field in the southern Po basin, northern Italy. - Diss. Univ Köln, Berichte Kernforschungsanlage Jülich, 2313:1-217

Publisher's Note Springer Nature remains neutral with regard to jurisdictional claims in published maps and institutional affiliations. 